\title{
Ralstonia solanacearum, Ganoderma australe, and bacterial wetwood as predictors of ironwood tree (Casuarina equisetifolia) decline in Guam
}

\author{
C. M. Ayin ${ }^{1}$ - A. M. Alvarez ${ }^{1}$ - C. Awana ${ }^{1}$ - F. M. Schleinzer ${ }^{1}$ - B. D. Marx ${ }^{2}$ - R. L. Schlub ${ }^{3}$ (D) \\ Received: 15 August 2018 / Accepted: 2 October 2019 / Published online: 12 November 2019 \\ (C) Australasian Plant Pathology Society Inc. 2019
}

\begin{abstract}
Ironwood (Casuarina equisetifolia subsp. equisetifolia) trees on Guam have been in decline since 2002. This study applied proportional odds logistic multiple regression modeling to a set of biological variables in order to find significant decline predictors as a first step towards identifying pathogenic contributors. Based on the analysis of a set of 77 medium and large trees, the bacterium Ralstonia solanacearum and the fungus Ganoderma australe species complex were found to be significant predictors, with $p$ values of $<0.001$ and $<0.008$, respectively. Their respective values for symptomless trees were $18 \%$ and $0 \%$, compared to $80 \%$ and $35 \%$ for those nearly dead trees of which $30 \%$ had both organisms and $15 \%$ had neither. More complex models were also fit, that included interactions. The $R$. solanacearum by G. australe interaction was not a strong effect, indicating additive rather than multiplicative behavior of these effects on decline severity ( $p$ value $>0.087$ ). When nine covariates were applied univariately to a data subset of 30 tree cross-sections, the significance of $R$. solanacearum was strongly upheld while that of $G$. australe was moderately reduced. Also significant were percent cross-sectional area with bacterial wetwood and the formation of ooze within $24 \mathrm{~h}$. Wetwood bacteria of Klebsiella spp. and $K$. oxytoca were found across all levels of decline and were not significant predictors. Other enteric bacteria identified included Kosakonia, Enterobacter, Pantoea, Erwinia, and Citrobacter.
\end{abstract}

Keywords Casuarina equisetifolia $\cdot$ Tree decline $\cdot$ Ralstonia solanacearum $\cdot$ Klebsiella $\mathrm{sp} \cdot \cdot$ Ganoderma australe $\cdot$ Wetwood TZC medium

\section{Introduction}

Casuarina equisetifolia subsp. equisetifolia, often referred to as ironwood, is indigenous to Southeast Asia, Malaysia, Northern Australia, Oceania (Potgieter et al. 2014) and possibly to Guam and the Northern Mariana Islands (Safford 1905). Casuarina equisetifolia is considered an integral member of Guam's natural landscape (Stone 1970; Fosberg et al. 1979).

R. L. Schlub

rlschlub@triton.uog.edu

1 Department of Plant and Environmental Protection Sciences, University of Hawaii at Manoa, 3190 Maile Way, Honolulu, HI 96822, USA

2 Department of Experimental Statistics, Louisiana State University, Baton Rouge, LA 70803, USA

3 University of Guam Cooperative Extension Service, Mangilao, GU 96923, USA
Pollen dating confirms its presence in Guam for hundreds of years (Athens and Ward 2004). A 2002 forestry inventory reported ironwood among the healthiest tree species on the island, based on a survey of over 115,000 ironwood trees larger than $12.7 \mathrm{~cm}$ in diameter at breast height (DBH) (Donnegan et al. 2004).

However, in the same year, a local farmer reported that five of his 10-year old ironwood trees, planted as part of a windbreak, exhibited symptoms of rapid yellowing and death. Cross-sections of these trees exhibited areas of wetwood that were dark, water infused, and radiated from their centers (Mersha et al. 2009; Mersha et al. 2010a; Schlub et al. 2011a). Droplets of bacterial ooze appeared inside and outside the wetwood stained areas. More numerous at the farm, and appearing elsewhere on Guam, were trees with the same cross-sectional symptoms but accompanied by thinning foliage and a lethal progressive dieback. This latter condition is now referred to as ironwood tree decline (IWTD) (Mersha et al. 2009; Mersha et al. 2010a; Schlub et al. 2011a). 
At the time, the presence of ooze was attributed entirely to nonpathogenic endophytes associated with bacterial wetwood and none to the bacterial wilt pathogen, Ralstonia solanacearum. Though it was known that wetwood had been reported in Casuarina in Mauritius as well as in other tree species in Indonesia (Supriadi and Sitepu, 2001), it had not been reported as a disease of Casuarina nor a symptom of bacterial wilt in China (Liang and Chen 1982) or India (Ali et al. 1991). Other than causing a reduction in lumber quality, the presence of wetwood is generally considered benign (Ward and Pong 1980; Jeremic et al. 2004) and the result either of microbial activity (principally bacteria), injury, or normal aging (Ward and Pong 1980; Jeremic et al. 2004).

Due to the belief that the observed bacterial ooze was composed of one or more species of wetwood bacteria and not $R$. solanacearum, other possible explanatory variables for IWTD were investigated. As a result of an island wide survey of 1427 trees, the level of management intensity, presence of basidiocarps, and termites were determined to be significant predictive variables (Schlub 2010; Schlub et al., 2011a). A survey conducted in Guam and Saipan in 2010 led to the conclusion that the Ganoderma australe species complex was the basidiocarp most likely responsible for decline (Mersha et al. 2011; Schlub et al. 2012a). In 2015, the prominent termite species infecting $93 \%$ of Guam's ironwood trees was determine to be Nasutitermes takasagoensis or a closely related species from the $N$. takasagoensis complex (Park et al. 2019).

The discovery in 2010 that wood drill shavings and ooze from infected trees tested positive for $R$. solanacearum using immunodiagnostic strips (Agdia, Inc.) (Mersha et al. 2010b; Schlub et al. 2011b; Schlub et al. 2012b) led researchers to suspect that this bacterial wilt pathogen may in fact play a role in IWTD. The rich bacterial flora associated with wetwood made it difficult to obtain pure cultures of $R$. solanacearum (Ayin et al. 2013; Schlub et al. 2013). Ayin et al. (2013, 2015) succeeded in purifying $R$. solanacearum as well as other bacteria from infected tree tissues using a semi-selective Ralstonia medium (mSMSA)(Engelbrecht 1994) and a modified Kelman's tetrozolium chloride medium (TZC)(Norman and Alvarez 1989). Shortly thereafter, these authors demonstrated that Guam's $R$. solanacearum strains causes wilting and death in ironwood seedlings (Ayin et al. 2013; Ayin et al. 2015). In addition to $R$. solancearum, Klebsiella spp. also dominated the cultures obtained from bacterial ooze emanating from diseased ironwood trees and were further identified as $K$. oxytoca and K. variicola (Ayin et al. 2013; Ayin et al. 2015). In other forest tree species, Klebsiella spp. are thought to play a role in the formation of wetwood (Hartley et al. 1961; Jeremic et al. 2004). With the failure of strains of Klebsiella to cause wilt of inoculated seedlings (Ayin et al. 2015), Klebsiella spp. were dismissed as possible aggressive pathogens of C. equisetifolia but were not ruled out as secondary or opportunistic pathogenic contributors to IWTD.

The primary cause or causes of IWTD remains elusive, yet in previous studies several possible biological variables have been identified. The aim of this study was to apply proportional odds logistic regression modeling to evaluate the significance of $R$. solanacearum and Ganoderma australe as predicators of IWTD. Additionally, we report the analyses of 30 tree cross-sections for $K$. oxytoca, ooze formation, and bacterial wetwood as predictors of decline.

\section{Materials and methods}

\section{Tree selection, processing, and data analyses}

Seventy-seven ironwood trees were visually inspected, sampled, and growth measurements recorded. Trunk diameter in centimeters was determined at breast height $(1.3 \mathrm{~m})(\mathrm{DBH})$. Also determined was tree height in meters. Through visual inspection, decline severity (DS) was recorded as one of five ordinal categories based on fullness of branches and dieback $(0=$ symptomless, $1=$ slight damage, $2=$ distinctly damaged, $3=$ heavily damaged, and $4=$ nearly dead) (Schlub et al. 2011a). The estimated percentage of bare branches associated with categories of DS for trees larger than $32 \mathrm{~cm} \mathrm{DBH}$ are 0,9 , 49, 67, and 98, respectively (Schlub et al. 2011a). Trees were selected randomly from 15 sites, of which 10 sites were used in previous studies (Fig. 1) (Schlub 2010; Schlub et al. 2011a; Schlub et al. 2011b). Each tree was examined for presence/ absence of the wood-rot fungus $G$. australe species-complex based on basidiocarp morphology. Tree drill shavings were assayed for $R$. solanacearum using $R$. solanacearum-specific immunostrip tests kits manufactured by Agdia Inc. of Elkhart, Indiana, USA (catalog number: STX 33900 and ISK 33900) (Ayin et al. 2015). The test kit consisted of a sample extract bag containing $3 \mathrm{ml}$ of BEB1 buffer and a test strip. The procedure involved placing $150 \mathrm{mg}$ of wood shavings in the extract bag, mixing thoroughly, dipping the end of the test strip into the solution, and then waiting for the appearance of a colored test line.

Secondly, a 30-tree subset of the original 77 trees was selected for further analyses. Symptomless trees and those with IWTD symptoms were sampled among the windbreaks on Mr. Bernard Watson's farm that formed part of the initial decline report in 2002. Site and soil descriptors included slope of 3-7 degrees, parent material coralline limestone, map unit Guam cobbly clay loam, and family clayey, gibbsitic, nonacid, isohyperthermic Lithic Ustorthents (Soil Survey Staff 2015). Using a chainsaw, trees were felled with a transverse cut 51$76 \mathrm{~cm}$ above the ground, followed by an additional cut to 
Fig. 1 Guam ironwood tree (Casuarina equisetifolia) survey map, 15 sites in the current study (shaded), 10 were a part of a previous survey of 38 sites, in which averages of decline severity (DS) were determined, $\mathrm{DS}=0$ (symptomless) to 4 (nearly dead) (Schlub et al. 2011a)

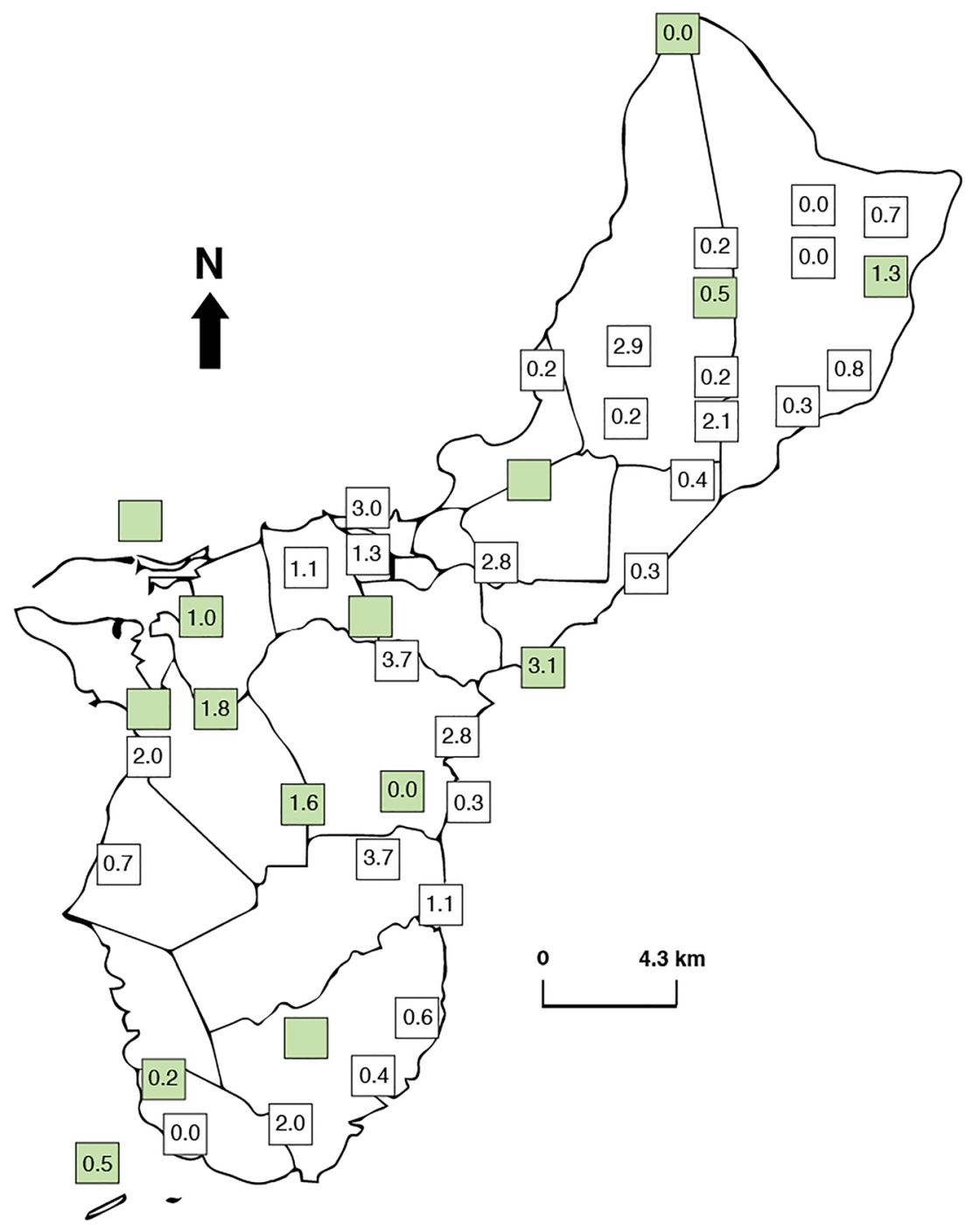

flatten the stump and clean the blade of any debris from previous cuts. Approximately $12 \mathrm{~cm}$ of bark was removed from the top of the stump. For analysis, a single $2.5-5 \mathrm{~cm}$ crosssectional disc/slice was removed from the top of each stump. To remove debris, cross-sections were wiped with a clean, moist paper towel.

Under laboratory conditions, cross-sections were photographed, sampled for bacteria, and examined for evidence of bacterial wetwood and $G$. australe wood-rot. Percent wetwood area was based on those areas that exhibited dark discoloration that radiated from the center of the section. Additionally, these areas had one or more of the following characteristics: higher moisture than adjacent tissue, a dark line of demarcation at its outer edge, and the presence of ooze. Cross-sections were examined for differences in ooze formation as a means of distinguishing ooze from $R$. solanacearum from that from wetwood bacteria. The presence or absence of ooze within $24 \mathrm{~h}$ was determined (ooze initiation). Ooze was recorded as one of three types: i) a viscous white to off-white substance (VO); ii) a watery, amber ooze (WO); or iii) a mixture of types i and ii (MO). Ooze quantity was recorded as the amount of ooze formed within $72 \mathrm{~h}$ : none, slight (less than 10 single drops) or abundant (10 or more single drops). For statistical purposes, the quantity score assignments were 0,1 , and 4, respectively. Evidence of G. australe wood-rot included soft white rot or the presence of mycelial strands characteristic of G. australe.

Within $24 \mathrm{~h}$, tree ooze and drill shavings were collected from cross-sections for bacterial analyses. Drill shavings from six holes $(2-3 \mathrm{~cm}$ deep and $0.5 \mathrm{~cm}$ in diameter, into the center, middle, and outer areas of each tree cross-section) were collected. Ralstonia solanacearum immunostrip testing was conducted on samples: either $150 \mathrm{mg}$ of wood shavings, $80 \mu \mathrm{L}$ of water from soaked drill shavings or a droplet of ooze. Shavings $(2 \mathrm{~g})$ from each hole were placed into $6 \mathrm{ml}$ of sterile water. Two $1 \mathrm{ml}$ subsets were transferred to $1.5 \mathrm{ml}$ Eppendorf microcentrifuge tubes for shipment to Hawaii. When present, ooze was scrapped from cross-sections and transferred to two 
empty $0.1 \mathrm{ml}$ Eppendorf microcentrifuge tubes for shipment. In both cases, the two tubes constituted a set for culturing and another for LAMP assay. The LAMP assay sample sets were treated in a simmering water bath for $10 \mathrm{~min}$ in an attempt to stop bacterial growth while preserving DNA.

The analysis of the ironwood decline data was performed using proportional odds logistic regression. An excellent introduction to these models can be found in Agresti (2019). The choice of the proportional odds logistic regression model was based on the fact that there were five ordinal levels of the response category IWTD. The statistical models and analyses were generated using SAS software, Version 9.4.

\section{Isolation, purification, DNA extraction of bacteria}

Culturable water samples were vortexed for $1 \mathrm{~min}$, then two to three loopfuls of the suspension were dilution streaked onto petri plates containing modified TZC medium (Norman and Alvarez 1989; $17 \mathrm{~g} / \mathrm{L}$ agar, $10 \mathrm{~g} / \mathrm{L}$ peptone, $5 \mathrm{~g} / \mathrm{L}$ glucose and $0.001 \% 2,3,5$-triphenyl-tetrazolium chloride) and then incubated at $26^{\circ} \mathrm{C}\left( \pm 2{ }^{\circ} \mathrm{C}\right)$. To the culturable ooze samples, $100 \mu \mathrm{l}$ of sterile deionized water containing $25 \mathrm{mg} / \mathrm{L}$ cycloheximide was added before vortexing and streaking. Two types of colonies were saved for further purifications: i) those resembling the raised, white colonies of Klebsiella with red to crimson centers and transparent margins and ii) colonies that did not appear to be Klebsiella but were similar enough in morphology to warrant further purification. Cultures were considered pure after a minimum of three successive single-colony isolations were achieved through dilution streaking onto TZC plates. Purified strains were cultured on peptone glucose medium (17 g/L agar, $10 \mathrm{~g} / \mathrm{L}$ peptone, $5 \mathrm{~g} / \mathrm{L}$ glucose) for short term storage at $4{ }^{\circ} \mathrm{C}$ and transferred to $1 \% \mathrm{w} / \mathrm{v}$ tryptone, $0.5 \%$ $\mathrm{w} / \mathrm{v}$ yeast extract containing $15 \% \mathrm{v} / \mathrm{v}$ glycerol for long term storage at $-80^{\circ} \mathrm{C}$.

DNA was extracted from cultures using either TrisEDTA buffer or a DNA purification kit. The buffer extraction consisted of taking a loopful of a single agar colony and placing it into $1 \mathrm{~mL}$ of Tris-EDTA (Tris$\mathrm{HCL} \mathrm{C}_{4} \mathrm{H}_{12} \mathrm{ClNO}_{3}$, disodium ethylenediaminetetraacetate: $\left.\mathrm{Na}_{2} \mathrm{C}_{10} \mathrm{H}_{14} \mathrm{O}_{8} \mathrm{~N}_{2} .2 \mathrm{H}_{2} 0\right)$ buffer (10 mM Tris-HCL; $\mathrm{pH}$ 7.5, $1 \mathrm{mM}$ EDTA; $\mathrm{pH} \mathrm{8.0)}$ and heated for $10 \mathrm{~min}$ at $95{ }^{\circ} \mathrm{C}$ in a heat block. The DNA purification kit consisted of growing a culture for approximately $10 \mathrm{~h}$ in yeast extract broth $(0.8 \% \mathrm{w} / \mathrm{v}$ peptone and $0.01 \%$ $\mathrm{w} / \mathrm{v}$ yeast extract) and then extracted using the Wizard Genomic DNA purification kit (Promega, Corp., Madison, WI) following the manufacturer's instructions. DNA extracted using both methods was quantified with a Nanodrop ND-100 Spectrophotometer (NanoDrop technologies, Inc., Rockland, DE) and adjusted to approximately $20 \mathrm{ng} / \mu \mathrm{L}$ with Tris-EDTA buffer.

\section{Presumptive identification of enteric bacteria and phylogenetic tree}

Purified strains were designated Gram negative or Gram positive based on the potassium hydroxide test (Gregersen 1978). Oxidation-fermentation tests (Hugh and Leifson 1953) were performed in 96 well plates containing $200 \mu \mathrm{L}$ of Difco OF basal medium (Becton, Dickinson and Co., Sparks, MD) supplemented with $1 \%$ glucose. Oxidase tests (Gordon and McLeod 1928) were performed on isolates transferred to glass slides with toothpicks. Single drops of oxidase reagent (Becton, Dickinson and Company, Sparks, MD) were added to the slides. Since culturing $R$. solanacearum is difficult in the presence of wetwood bacteria, tree samples were assessed for the presence or absence of $R$. solanacearum by LAMP assessment of the heat-treated samples.

The 16S rDNA PCR was carried out in a $10 \mu \mathrm{L}$ reaction containing $5 \mu \mathrm{M}$ of the primer pair fd1 (5'-AGA GTT TGA TCC TGG CTC AG-3') and rp2 (5'-ACG GCT ACC TTG TTA CGA CTT-3') (Weisburg et al. 1991), 1X Jumpstart REDtaq Ready Mix (Sigma-Aldrich, St. Louis, MO) and $1 \mu \mathrm{L}$ of purified DNA ( $\sim 20 \mathrm{ng}$ ). PCR amplification reaction conditions were as follows: a denaturing step at $94{ }^{0} \mathrm{C}$ for $7 \mathrm{~min}$, followed by 30 cycles of $94{ }^{0} \mathrm{C}$ for $30 \mathrm{~s}, 55^{\circ} \mathrm{C}$ for $1 \mathrm{~min}, 72{ }^{\circ} \mathrm{C}$ for $2 \mathrm{~min}$, with a final step at $72{ }^{\circ} \mathrm{C}$ for $2 \mathrm{~min}$ to allow for elongation of all PCR products. PCR products were verified by gel electrophoresis on a $1.5 \%$ agarose gel stained with ethidium bromide. For sequencing, excess primers and nucleotides were removed using ExoSap-It (Affymetrix Inc., Santa Clara, CA) according to the manufacturer's instructions.

The phylogenetic relationships between the putative Klebsiella strains isolated from ironwood tissues and known Klebsiella strains as well as related species were determined by $16 \mathrm{~S}$ sequence analysis. Comparisons were also made with Klebsiella strains A6125-A6128 previously isolated in Guam (Ayin et al. 2013). Sequencing was performed at the Biotech Core facility, University of Hawaii at Manoa. Trees were rooted using an orthologous sequence from Vibrio cholerae strain ATCC 14035 (NCTC 8021) while reference strain sequences were obtained from the National Center of Biotechnology Information database. The analysis involved 53 nucleotide sequences. Codon positions included were $1 \mathrm{st}+2 \mathrm{nd}+3 \mathrm{rd}+$ Noncoding. There were a total of 1517 positions in the final dataset. The evolutionary history was inferred using the Maximum Parsimony method in MEGA X (Kumar et al., 2018), applying the Subtree-Pruning-Regrafting (SPR) algorithm with search level 1 in which the initial trees were obtained by the random addition of sequences (10 replicates).

Five strains representing different genera, identified through $16 \mathrm{~S}$ sequence analysis, were further characterized. BIOLOG identification scores were obtained using BIOLOG Gen III plates, MicroStation reader and database (BIOLOG, Hayward, CA, and U.S.A). Identification scores 
for the API system required access to the API online identification website (API web, https://apiweb.biomerieux.com). An immunoblot assay was performed on the purified isolates (Kaneshiro 2003; Alvarez et al. 2005) with modifications (Yasuhara-Bell et al. 2015). Immunoblots were analyzed with the aid of a dissecting scope. LAMP reactions were performed using previously established primers and protocols (YasuharaBell et al. 2015). Primers developed specifically for $K$. oxytoca and $K$. variicola were used individually with $5 \mu \mathrm{L}$ of DNA extracted with Tris-EDTA or purification kit. LAMP reactions were run using an iQ5 Multicolor Real-Time PCR detection system (Bio-Rad, Hercules, CA) for $40 \mathrm{~min}$ at $65^{\circ} \mathrm{C}$, with fluorescence readings at 30 -s or 1-min intervals.

\section{Results}

\section{Tree survey and analyses}

The presence of both $R$. solanacearum and $G$. australe was widespread across Guam. At the 15 survey sites used in this study (Fig. 1), 11 were positive for $R$. solanacearum and 7 for $G$. australe. At least one of these organisms was found in sites that had a decline severity level of 1 or greater in 2009 (Fig. 1). From a summary of the 77-tree data set (Table 1), the frequency of $R$. solanacearum and $G$. australe increased both singularly and together with increased decline severity. Ralstonia solanacearum was found in $18 \%$ of the symptomless trees, while neither organism was found in $15 \%$ of the nearly dead trees. The trees' DBH and height, ranged from 15 to $79 \mathrm{~cm}$ to 4-21 m, respectively.

A proportional odds logistic regression model using 77 trees was fit with the covariates $\mathrm{DBH}, R$. solanacearum and G. australe. The DBH ( $p=0.33)$, as well as height $(p=0.25)$, were found to be non-significant predictors of decline, whereas $G$. australe was found to be significant $(p<0.008)$ and $R$. solanacearum was found to be highly significant $(p<$ 0.001). As a further note of goodness-of-fit, the proportional odds model chi-square yielded a good fit $(p>0.18)$. Interaction effects were also explored. The $R$. solanacearum by $G$. australe interaction was not a strong effect, indicating an additive rather than a multiplicative behavior of these effects on decline severity ( $p$ value $>0.087$ ). Further, the results can be interpreted such that if a tree exhibits Ganoderma basidiocarps, the odds of that tree being symptomless on the ordinal scale (DS 0-4) is reduced by $75 \%$, when $R$. solanacearum is held fixed. If $G$. australe is held fixed and a tree tests positive for $R$. solanacearum, the odds of that tree being symptomless is reduced by $78 \%$ in comparison to the absence of $R$. solanacearum. Said differently, the reciprocal of the odd-ratios states that the odds of a symptomless classification is estimated to be approximately 4.5 times greater when a tree tests negative for $R$. solanacearum, holding $G$. australe fixed and 4.0 times greater when a tree tests negative for $G$. australe, holding $R$. solanacearum fixed.

It is also interesting to look more closely at the estimated response category probabilities from a model involving only $R$. solanacearum and $G$. australe. The following values were obtained using a model based on AIC 235.6, which only considers their main effects to model the ordinal disease response scale (DS 0-4). The estimated response category probability profiles were $(0.41,0.24,0.16,0.11$, and 0.08$)$ with both absent; $(0.15,0.17,0.21,0.23$, and 0.25$)$ when only $G$. australe was present; $(0.14,0.16,0.20,0.23$, and 0.27$)$ when only $R$. solanacearum was present; and $(0.04,0.06,0.10,0.20$, and 0.60 ) when both were present. These values clearly show how DS leans towards higher levels, when either or both are present and in the opposite direction if neither are present. If the model were to include DBH or Height, the AIC value would be slightly larger (unfavorable). Including the interaction term between $R$. solanacearum and $G$. australe did improve AIC slightly (234.1), but as stated the term was not statistically significant.

\section{Tree cross-sections and analyses}

Increases in IWTD severity was linked to increased wetwood and ooze formation. In sites with high decline incidences, it is not uncommon to find a heavily damaged tree (DS $=3$ ) with a cross-section showing severe wetwood and heavy ooze formation next to a slightly damaged tree $(\mathrm{DS}=1)$ with a crosssection containing no wetwood or ooze (Fig. 2). In DS =3-4
Table 1 Survey results of 77 ironwood trees (Casuarina equisetifolia) in Guam, evaluating the presence and absence of Ralstonia solanacearum (Rs) and Ganoderma australe $(\mathrm{Ga})$ across five levels of decline severity

\begin{tabular}{llllll}
\hline $\begin{array}{l}\text { Number of } \\
\text { trees }\end{array}$ & $\begin{array}{l}\text { Decline } \\
\text { severity }^{\mathrm{a}}\end{array}$ & $\begin{array}{l}\text { Rs } \\
\text { singular }^{\mathrm{b}}\end{array}$ & $\begin{array}{l}\text { Ga } \\
\text { singular }^{\mathrm{b}}\end{array}$ & $\begin{array}{l}\text { Rs and Ga } \\
\text { combined }\end{array}$ & $\begin{array}{l}\text { Rs and Ga } \\
\text { absent }\end{array}$ \\
\hline 17 & 0 & $18 \%$ & $0 \%$ & $0 \%$ & $82 \%$ \\
12 & 1 & $33 \%$ & $0 \%$ & $8 \%$ & $58 \%$ \\
13 & 2 & $62 \%$ & $0 \%$ & $23 \%$ & $15 \%$ \\
15 & 3 & $33 \%$ & $27 \%$ & $20 \%$ & $20 \%$ \\
20 & 4 & $50 \%$ & $5 \%$ & $30 \%$ & $15 \%$ \\
\hline
\end{tabular}

${ }^{\text {a }}$ Decline severity, DS $=0$ (symptomless) to 4 (nearly dead)

${ }^{\mathrm{b}}$ Highly significant predictor of decline with proportional odds logistic regression 


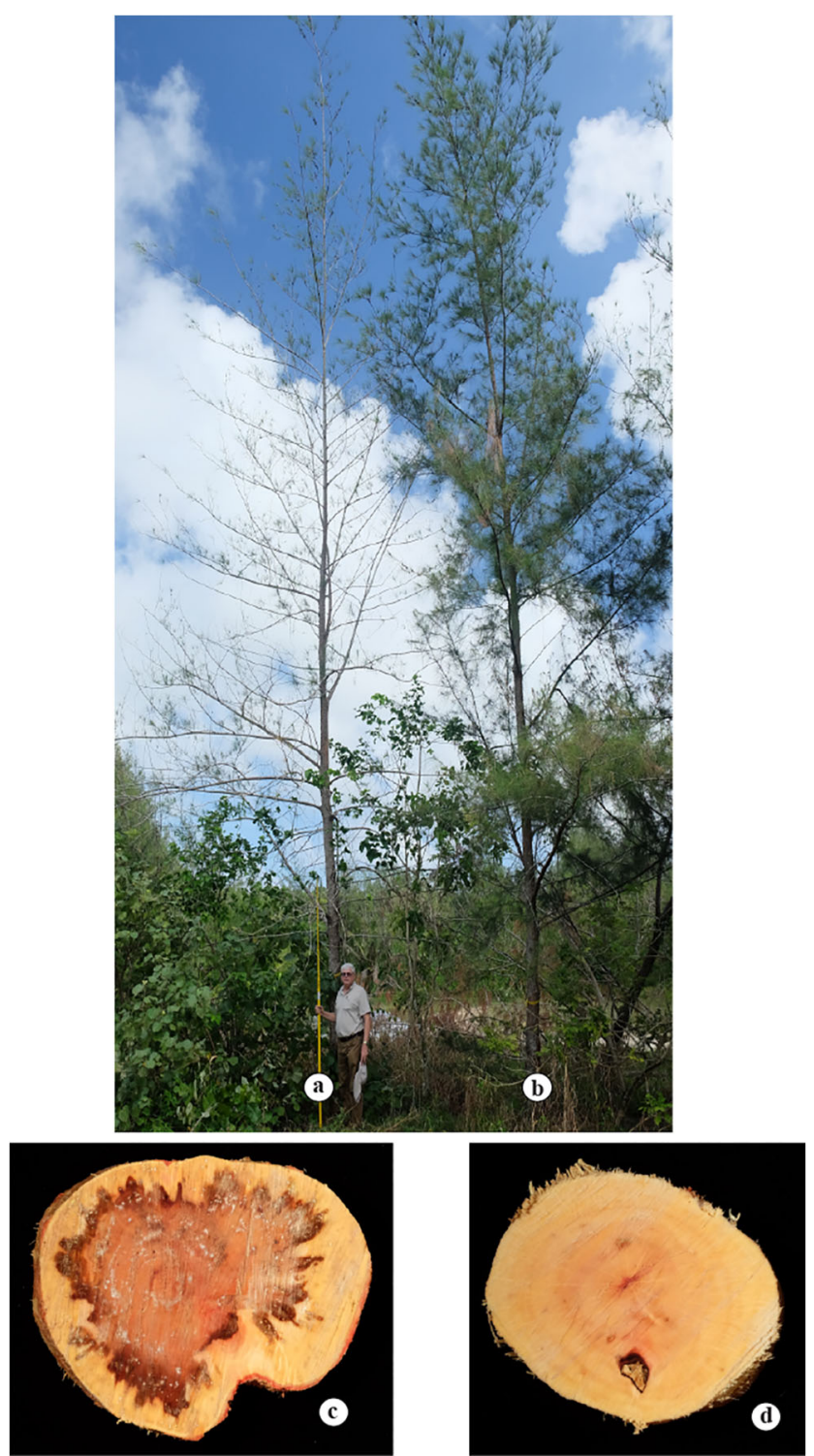

Fig. 2 Ironwood tree decline (Casuarina equisetifolia) symptoms: (a) heavily damaged tree (DS =3); (b) slightly damaged tree (DS =1); (c) cross-section of tree 'a' $5 \mathrm{~h}$ after sectioning, wetwood area $=58 \%$, ooze extensive, positive for Ralstonia solanacearum; (d) cross-section of tree 'b' $5 \mathrm{~h}$ after sectioning, wetwood area $=0 \%$, no ooze, positive for $R$. solanacearum and Klebsiella colony types other than K. oxytoca

level trees, ooze often appeared on the surface of crosssections immediately after cutting and, in some cases, the cut sections continued to ooze for another 3 days. When wetwood was present in DS $=0$ trees, it was limited to the heartwood and had little or no ooze associated with it (Fig. 3). When Ganoderma wood-rot and wetwood occurred in the same tree, the wetwood area was always larger than that of wood-rot (Fig. 4a). Wetwood often formed at the advancing edge of mycelial growth and cross-sections with $G$. australe often produced fresh mycelial growth after three to 4 days in a moisture chamber (Fig. 4b). Three forms of ooze were observed: viscous ooze (VO), watery amber substance (WO),

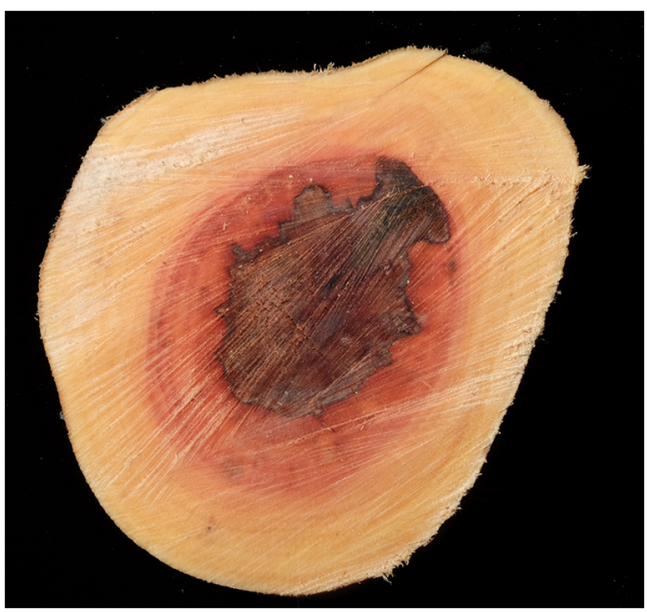

Fig. 3 Cross-section of a symptomless ironwood tree (Casuarina equisetifolia) ( $\mathrm{DS}=0$ ), $5 \mathrm{~h}$ after sectioning. Wetwood area $=17 \%$, ooze slight, positive for Ralstonia solanacearum, Klebsiella oxytoca, and other Klebsiella colony types

and mixtures of the two (MO) (Fig. 5). Drops of VO often tested positive for $R$. solanacearum and were most common in the sapwood and in unstained tissue. Drops of WO often tested negative for $R$. solanacearum and were most common in the heartwood-sapwood transition zone and in stained tissue. Drops of VO and MO were not randomly distributed, but appeared to coincide with growth rings (Fig. 2c).

The analysis of the 30-tree data subset showed trends for increased presence of $R$. solanacearum, G. australe, wetwood, and ooze initiation with increased severity of ironwood decline (Table 2). Ralstonia solanacearum, G. australe, and wetwood and ooze initiation were recorded in $87 \%, 33 \%$, $93 \%$, and $83 \%$ of the tree cross-sections across all levels of decline, respectively, of which symptomless trees contributed $7 \%, 0 \%, 17 \%$, and $7 \%$, respectively. The percentage of trees testing positive for $R$. solanacearum was the same using the Agdia immunostrip, LAMP, and culturing methods. Samples from 16 different trees were positive for $K$. oxytoca and occurred across all levels of decline. Klebsiella colony types not identified as $K$. oxytoca also occurred across all levels of decline.

A proportional odds logistic model was fit with nine covariates identified in Table 2 . Due to the relatively small sample size, covariates were fit individually, as it is unrealistic to assume that 30 observations could steer nine parameters for five ordered categories. Nonetheless, these univariate models can be insightful for main effects of regressors that are associated with decline. With an increased sample size, multiple regression models with and without interaction terms could further be explored. Note that the exploration of the $R$. solanacearum by $G$. australe interaction is not possible for the reduced data set, since there were no data (zero counts across all DS levels) for the $R$. solanacearum absent and G. australe present combination. Three covariates were found 
Fig. 4 Cross-section of a severely declined ( $\mathrm{DS}=3$ ) ironwood tree (Casuarina equisetifolia).

Wetwood area $=68 \%$, positive for Ganoderma australe and

Ralstonia solanacearum. (a) $5 \mathrm{~h}$ after sectioning, ooze slight; (b) close-up of the mycelial growth present after 3 days in moisture chamber, wetwood forms at the advancing edge of the mycelial growth indicated by arrow
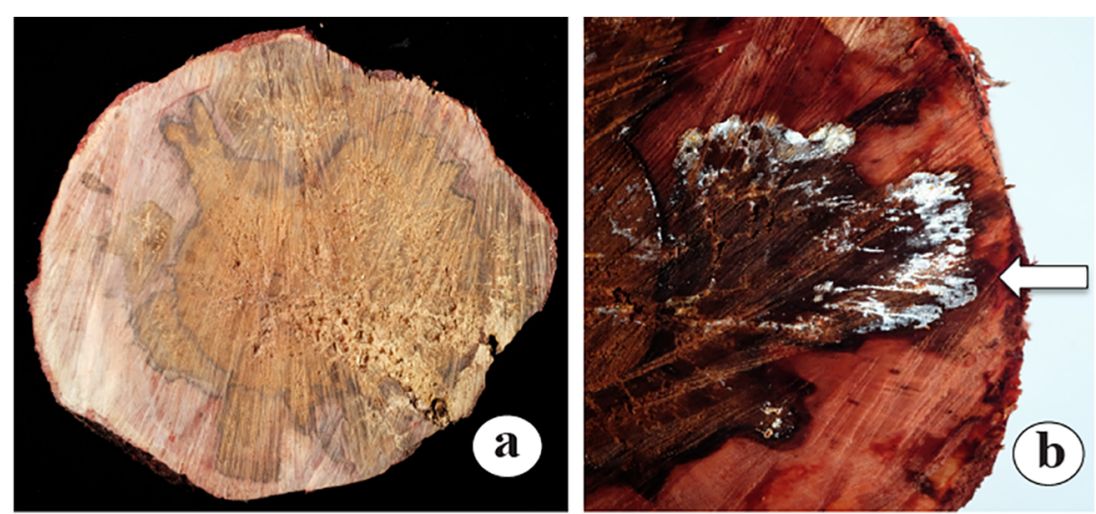

to be highly significant: percent wetwood, ooze initiation, and $R$. solanacearum, whereas the significances of $G$. australe was borderline (Table 3 ). It is interesting to note that $R$. solanacearum significances in the 77-trees model was upheld, while that of G. australe was reduced. In all cases, the proportional odds model satisfied the chi-square goodness-offit $(p>0.60)$. Table 3 shows that as the percent wetwood in a section increased by one unit, there is an estimated $5.5 \%$ decrease in the odds of falling into the healthy direction (relative to the unhealthy direction). Additionally, with the presence of $R$. solanacearum, G. australe and the early initiation of ooze, there was an estimated $97.8 \%, 76 \%$, and $94.2 \%$ decrease in the odds of falling into the healthy direction (relative to the unhealthy direction), respectively.

\section{Bacterial isolations and identifications}

Numerous bacterial colony types were observed on culture plates containing TZC (Fig. 6). Seventy-five isolates that displayed morphologies sufficiently similar to Klebsiella (mucoid, raised) colonies, with smooth margins

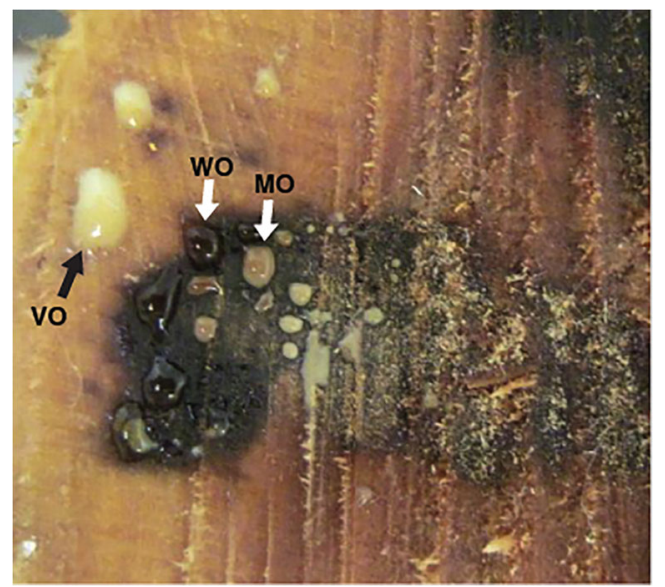

Fig. 5 Ooze types found in a declining ironwood trees $(\mathrm{DS}=2)$ (Casuarina equisetifolia) that tested positive for Ralstonia solanacearum and wetwood bacteria: $\mathrm{VO}=$ viscous, white to off-white substance; $\mathrm{WO}=$ watery, amber substance; $\mathrm{MO}=\mathrm{a}$ mixture of the viscous and watery ooze with or without crimson centers, were obtained (Fig. 6a). After further colony development and inspection, 30 potential Klebsiella isolates were identified. Three tests used for initial presumptive identification of enteric bacteria indicated that the 30 strains were Gram negative, oxidase negative and fermented glucose. All 30 of these cultures were negative when tested by LAMP using $K$. variicola specific primers. It was determined that colony growth on TZC is not a reliable means to identify $R$. solanacearum when wetwood is present due to similarities in colony morphology with Klebiella and other wetwood bacteria (Fig. 6b). In addition, when TZC was used with mixed cultures, Klebiella spp. masked the less prolific and slower growing $R$. solanacearum.

The phylogenetic relationships among the 30 putative Klebsiella, S-strains (Schlub strains) from the current study and four A-strains (Alvarez strains) obtained previously (Ayin et al. 2015) were determined by $16 \mathrm{~S}$ sequence analysis (Fig. 7). The phylogeny showed that the cultures were closely related to six different genera: Kosakonia, Enterobacter, Pantoea, Erwinia, Citrobacter, and Klebsiella. Of the 34 cultures, four were closely related to $K$. variicola and five to $K$. oxytoca. Three of the strains (S69-1A1, S98-3A1, S105-1A1) were related to Enterobacter cloacae a wilt pathogen of mulberry (Morus alba) in China (Wang et al. 2008).

A subset of the above strains was selected for further testing (Table 4). The Microlog ${ }^{\mathrm{TM}}$ multi-substrate metabolic analysis confirmed the $16 \mathrm{~S}$ results for strains S752A1, S34-1A1, and S50-3A1 as Pantoea, Enterobacter, and Citrobacter, respectively. Though S73-1A1 was identified as Klebsiella by $16 \mathrm{~S}$ rDNA sequencing, the API NE test and Microlog $\mathrm{TM}$ indicated that it is more likely Enterobacter. In addition, the strain also was motile and unable to ferment lactose on MacConkey agar (MacConkey 1990). Though strain S38-1A1 was identified as Erwinia by $16 \mathrm{~S}$ rDNA sequencing and by its updated genus name Pectobacterium with Microlog, it could possibly be Klebsiella because the strain was non-motile and positive for lactose fermentation (Brenner et al. 2005). 
Table 2 Stem cross-section analyses of 30 ironwood trees (Casuarina equisetifolia) in Guam, across five levels of decline severity

\begin{tabular}{|c|c|c|c|c|c|}
\hline \multirow{3}{*}{ Variable } & \multicolumn{5}{|c|}{ Decline Severity (DS) ${ }^{a}$} \\
\hline & 0 & 1 & 2 & 3 & 4 \\
\hline & 5 trees & 5 trees & 6 trees & 6 trees & 8 trees \\
\hline Height $\mathrm{m}$ (range) & $13-16$ & $12-16$ & $04-15$ & $12-16$ & $10-16$ \\
\hline Diameter in $\mathrm{cm}$ at $1.3 \mathrm{~m}$ (range) & $15-20$ & $13-23$ & $16-20$ & $14-19$ & $16-25$ \\
\hline Percent wetwood area (range) $(\%)$ & $3-17$ & $0-66$ & $0-77$ & $58-80$ & $56-87$ \\
\hline Ooze initiation within $24 \mathrm{~h}(\%)$ & 40 & 80 & 83 & 100 & 100 \\
\hline \multicolumn{6}{|l|}{ Ooze quantity } \\
\hline None within 72 h (\%) & 20 & 40 & 16 & 0 & 0 \\
\hline Slight ooze within 72 h (\%) & 0 & 0 & 16 & 0 & 13 \\
\hline Abundant ooze within $72 \mathrm{~h}(\%)$ & 80 & 60 & 68 & 100 & 87 \\
\hline \multicolumn{6}{|l|}{ Ooze type } \\
\hline Viscous (\%) & 20 & 60 & 83 & 100 & 100 \\
\hline Watery $(\%)$ & 80 & 60 & 50 & 67 & 50 \\
\hline Mixture (\%) & 20 & 20 & 0 & 0 & 25 \\
\hline Klebsiella colony types ${ }^{b}$ & 80 & 80 & 83 & 67 & 63 \\
\hline Klebsiella oxytoca $^{\mathrm{c}}$ & 40 & 60 & 83 & 67 & 25 \\
\hline Ralstonia solanacearum & 40 & 80 & 100 & 100 & 100 \\
\hline Ganoderma australe & 0 & 20 & 33 & 50 & 50 \\
\hline
\end{tabular}

\section{Discussion}

Ganoderma, a genus of more than 300 species of wooddecaying fungi, has been reported as a wood decay pathogen of C. equisetifolia throughout its natural habitat and in many areas where ironwood has been introduced including Mexico (Cibrián et al. 2007), India (Bakshi 1951; Mohanan and Sharma 1993; Foroutan and Jafary 2007), Pacific islands (Kohler et al. 1997), Indonesia and Malaysia (Glen et al. 2009). Unfortunately, reports of pathogenicity are often based on the presence of fruiting bodies on living trees and not supported by Koch's postulates. Though completing Koch's is beyond the scope of this study, evidence to support G. australe as a likely causal agent includes the presences of fruiting bodies in IWTD tree sites, the significants of fruit bodies as predicitors of decline in the study and previous studies (Schlub 2010; Schlub et al., 2011a). In addition, examination of cross-sections showed colonization by G. australe is not limited by the non-living heartwood, but extends into live sapwood (Fig. 4), which is indicitive of a pathogen.

Ralstonia solanacearum is a widespread bacterial pathogen that infects more than 200 hosts, comprising 53 botanical families (Hayward 1991). Genetic diversity in a global collection of $R$. solanacearum strains has led to the characterization of $R$. solanacearum as a species complex (Fegan and Prior 2005). Strains of $R$. solanacearum have been reported to cause bacterial wilt of ironwood in several countries including India (Ali et al. 1991; Mohanan and Sharma 1993), China (Liang and Chen 1982), and Mauritius (Orian 1961). Though isolates of $R$. solanacearum were found to be pathogenic on tomato and ironwood seedlings (Ayin et al. 2015), the ironwood trees from which the isolates were collected had symptoms of IWTD and not those of bacterial wilt reported in India (Ali
Table 3 Proportional odds models fits of 30 ironwood trees (Casuarina equisetifolia) crosssectional covariates that are significant when fit univarately

\begin{tabular}{|c|c|c|c|c|}
\hline Covariate & $P$ value & $\begin{array}{l}\text { Odds- } \\
\text { ratio }\end{array}$ & Odds-ratio confidence interval & Goodness-of-fit $p$ value \\
\hline Percent wetwood area & $<0.0001$ & 0.945 & $(0.904 ; 0.968)$ & 0.64 \\
\hline Ooze initiation & 0.007 & 0.058 & $(0.007 ; 0.464)$ & 0.90 \\
\hline $\begin{array}{l}\text { Ralstonia } \\
\quad \text { solanacearum }\end{array}$ & 0.005 & 0.022 & $(0.001 ; 0.319)$ & 0.94 \\
\hline Ganoderma australe & 0.052 & 0.240 & $(0.057 ; 1.011)$ & 0.72 \\
\hline
\end{tabular}


Fig. 6 Bacterial colony types streaked from ironwood tree (Casuarina equisetifolia) tissue on to tetrazolium chloride medium (TZC) (a) Purified Klebsiella species, note the rounded, raised, pink colonies with white borders; (b) colonies from raw bacterial wetwood ooze

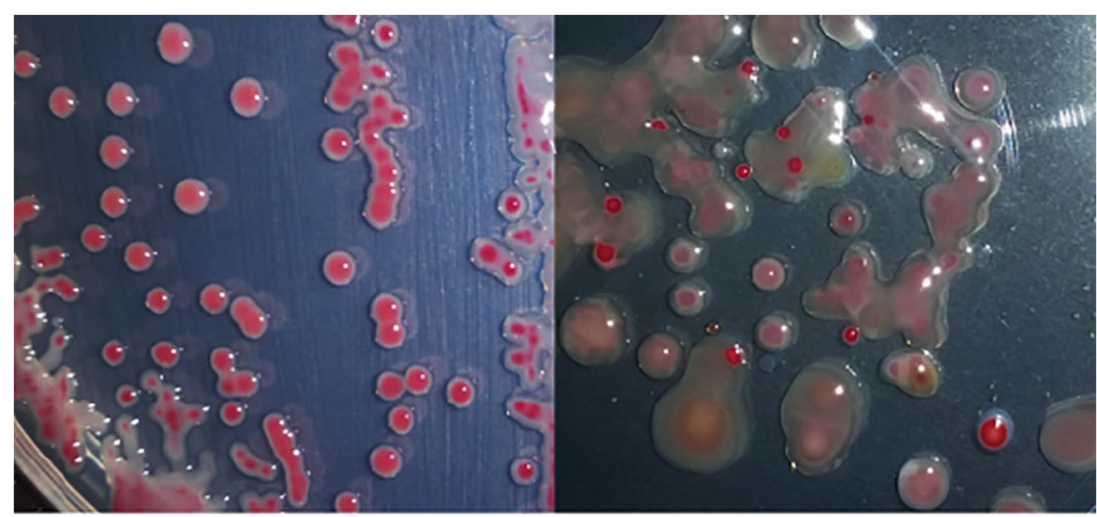

(a)
Fig. 7 Maximum Parsimony tree derived from $16 \mathrm{~S}$ sequence analysis of 34 bacterial isolates from ironwood trees. Those with $\mathrm{S}$ numbers were derived from the current study (GenBank accession numbers MK968734MK968763), whereas A6125A6128 were from a previous study (Ayin et al. 2015). The bootstrap consensus tree, inferred from 2000 replicates, is taken to represent the evolutionary history of the taxa analyzed. Branches corresponding to partitions reproduced in less than $50 \%$ bootstrap replicates are collapsed. The percentage of replicate trees in which the associated taxa clustered together in the bootstrap test are shown next to the branches

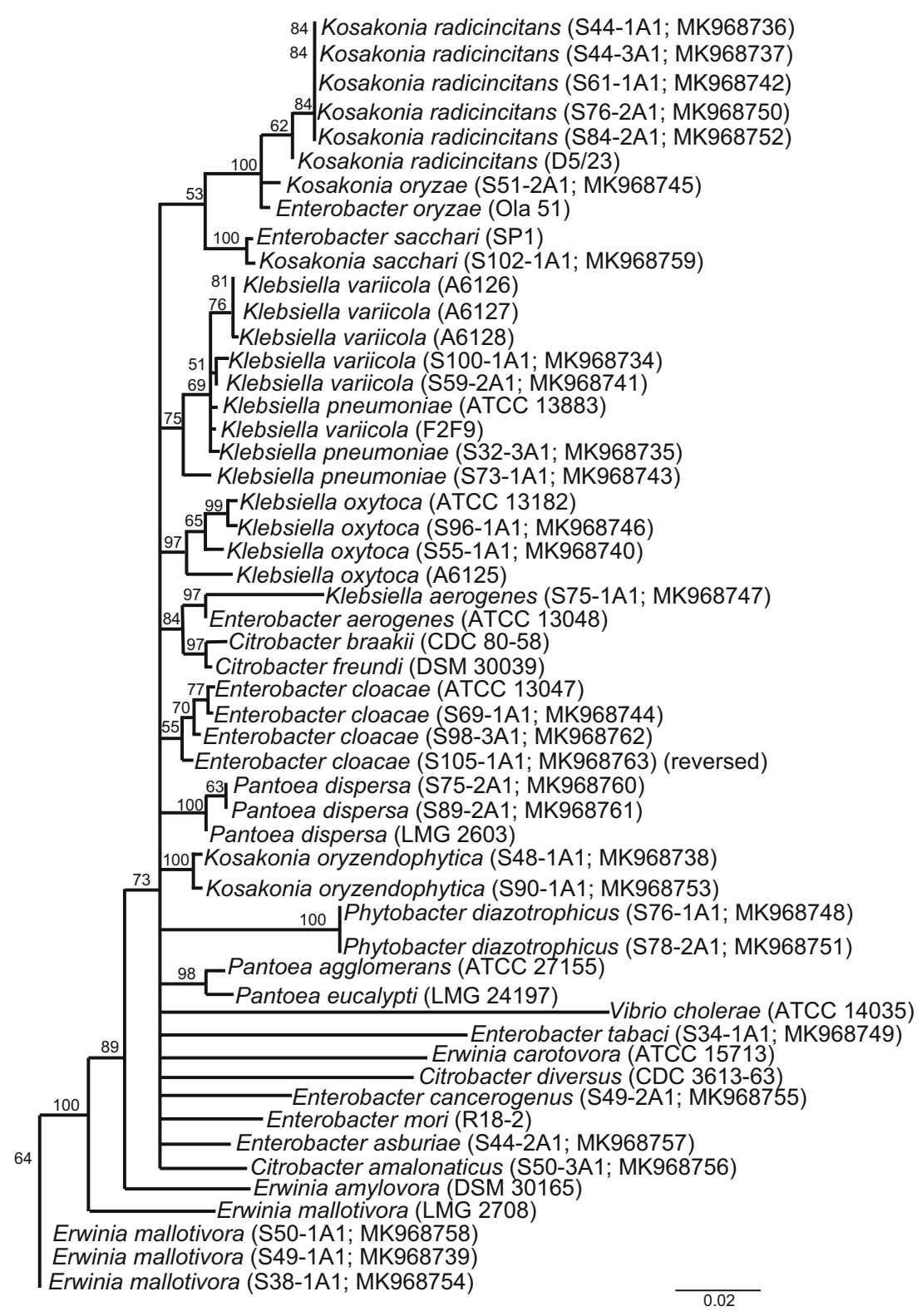


Table 4 Identification of bacterial endophytes associated with symptomatic wetwood tissue, sequence analysis, and metabolic profiles

\begin{tabular}{llllll}
\hline$\#$ & Sample \# & 16S rDNA & Microlog TM & SIM $^{\text {b }}$ & MacConkey test \\
\hline 1 & S73-1A1 & Klebsiella & Enterobacter & Motile & - \\
2 & S75-2A1 & Pantoea & Pantoea & Motile & - \\
3 & S34-1A1 & Enterobacter & Enterobacter & Motile & - \\
4 & S50-3A1 & Citrobacter & Citrobacter & Motile & - \\
5 & S38-1A1 & Erwinia & Pectobacterium & Non-motile & $+{ }^{\text {c }}$ \\
\hline
\end{tabular}

${ }^{\text {a }}$ Oxidation of carbon compounds using MicroLog ${ }^{\mathrm{TM}}$ (Biolog, Inc., Hayward, CA)

${ }^{\mathrm{b}} \mathrm{SIM}=$ sulfide indole motility medium

${ }^{\mathrm{c}}$ Fermentation of lactose on MacConkey agar et al. 1991; Mohanan and Sharma 1993) or China (Liang and Chen 1982). With IWTD, death is gradual, often taking years. It usually appears at the onset of reproductive maturity, is frequently associated with wetwood and G. australe heartwood rot and is most frequently found in windbreaks and landscape planting (Schlub et al. 2011a; Schlub et al. 2012a). The typical reports for bacterial wilt include rapid death, often within weeks of onset. It usually first appears at the young saplings stage and is mainly associated with densely planted plantations or nurseries (Liang and Chen 1982; Ali et al. 1991).

In a previous study using BOX-PCR profiling (Kogan et al. 1987; Saitou and Nei 1987), little genetic diversity was revealed among $R$. solanacearum strains isolated from ironwood in Guam (Ayin et al. 2015). The Guam ironwood strains were assigned as phylotype I (Ayin et al. 2015), which are thought to have originated in Asia (Fegan and Prior 2005). Interestingly, $R$. solanacearum strains isolated from Guam ironwood displayed RIF marker (dnaA) (Schneider et al. 2011) sequence similarities to a $R$. solanacearum strain isolated from ironwood in China (Ayin et al. 2015). The genetic diversity of $R$. solanacearum strains infecting ironwood in Guam merits additional investigation.

In this study, the presence of ooze in cross-sections is attributed to infection by the bacterial wilt pathogen $R$. solanacearum and/or by bacteria from at least six wetwood genera within the family Enterobacteriaceae. This group of closely related, glucose-fermenting, gram negative rodshaped bacteria, that are abundant in soil, water, plants, and the intestines of animals. The wetwood bacteria isolated from ironwood tissues in this study, with and without wetwood, were also isolated from other woody tree species in previous studies (Hartley et al., 1961; Tiedemann et al. 1977; Schink et al., 1981; Murdoch and Campana 1983; Jeremic et al. 2004). Recent studies have shown that bacterial species found in the genera identified in our study also possess plant growthpromoting properties (Magnani et al. 2010; Quecine et al. 2012; Witzel et al. 2012; Zhu et al. 2012; Chen et al. 2013; Weber et al. 2013; Wei et al. 2013) and this may explain their association with trees often found in nutrient deficient soils. These same properties may also explain what appears to be the promotion by bacterial wetwood of $G$. australe colonization beyond the heartwood tissue in declining ironwood trees.

Though the occurrence of wetwood is useful in predicting IWTD, why it forms, its role in IWTD, and how to detect it without destructive sampling needs to be determined. Wetwood bacteria appear to be omnipresent in Guam, as $K$. oxytoca and bacteria with Klebsiella type colonies were consistently isolated across all levels of decline (Table 2). Although they were not significant predictors of decline, manifestations of bacterial wetwood colonization in the form of percent wetwood and the initiation of ooze were significant (Table 3). Even though wetwood occurred in $93 \%$ of the 30 cross-sections, it only appeared to impact the health of a tree if the percent wetwood area was greater than $55 \%$, which was true for all the DS $=3$ and 4 trees and none of the DS $=0$ trees (Table 2). Two $R$. solanacearum positive trees are show in Fig. 2; however, only the tree with ooze and severe wetwood showed heavy decline damage. A possible explanation is that wetwood bacteria are behaving as opportunistic pathogens and might only be contributing to decline when the barrier between heartwood and sapwood is breached as a result of the inhibition of water conduction, which has been shown in the case of Salix (Sakamoto and Sano, 2000).

Due to the slow progression of IWTD and its general sporadic nature, it is likely that IWTD could be reduced through increasing (1) the genetic diversification of its tree population, (2) removal of $R$. solanacearum and G. australe infected trees, (3) limiting bacterial movement through equipment and rootgrafts, and (4) the application of cultural practices that promote healthy growth. The presence of $R$. solanacearum and Klebsiella colony types in symptomless trees seems to support the concept that a tree could possibly remain symptomless though infected with $R$. solanacearum and wetwood bacteria, provided the percent wetwood area and ooze formation remains minimal.

In conclusion, this study provides evidence that the bacterium $R$. solanacearum and, to a lesser degree, the fungus $G$. australe are significant predictors of IWTD on the island of Guam and that further research is required to determine causality. The results of the statistical analyses are aligned with those expected from two primary pathogens acting 
independent of each other. This is supported by the fact that $33 \%$ of DS $=3$ trees were positive for $R$. solanacearum in absence of $G$. australe while $27 \%$ of the trees with $G$. australe were negative for $R$. solanacearum. Future research should focus on detection, since the sensitivity of trunk drill shaving to detect early root infection by $R$. solanacearum is not known nor is the time lag between infection by G. australe and the appearance of fruiting bodies known. There is evidence that wetwood bacteria are playing a supportive role in decline when infection results in a percent wetwood area of $55 \%$ or greater and accompanied by early ooze formation. The appearance of both $R$. solanacearum and $K$. oxytoca in symptomless and slightly damaged trees raises the possibility that they can exist as asymptomatic infections. The presence of $R$. solanacearum in asymptomatic trees could also be the result of avirulent isolates or strains (Ayin et al. 2015). Additional studies and surveys are needed to determine the extent to which ironwood trees in Guam are infected with $R$. solanacearum, as well as the genetic profile of ironwood isolates. This study provides evidence that the loss of trees on Guam is better described as a disease syndrome than a decline. Facts identified in this study that are common with the concept of disease and contrary to decline included the following: (1) symptomless and unhealthy trees are often found adjacent to each other, (2) specific contributing factors are known, and (3) the condition is not restricted to mature trees. With the establishment that Enterobacter species are capable of causing bacterial wilt of mulberry in China (Wang et al. 2008; Zhu et al. 2011), a thorough phytopathogenic evaluation of Guam's ironwood wetwood bacteria is warranted. Studies of the diversity and characteristics of the bacterial flora of ironwood and their interactions with $R$. solanacearum, G. australe, and termites should provide a better understanding of the ecology of Guam's ironwood trees and the etiology of IWTD.

Acknowledgements This work was supported in part by the National Institute of Food and Agriculture, U.S. Department of Agriculture, McIntire Stennis project, under accession number 1005476 and the University of Guam Cooperative Extension Service and the University of Hawaii Foundation project in Plant Disease Control. The Authors gratefully acknowledge Joe Afaisen, Roger Brown, and Victoria Santos for their help on this project and to Dr. Zelalem Mersha and Karl Schlub for their early contributions to understanding IWTD. Greatly appreciated are Karl Schlub's photographic contributions and Dr. Mohammad Arif's phylogenetic tree contribution.

\section{References}

Agresti A (2019) An introduction to categorical data analysis, 3rd edn. Wiley, New York

Ali MIM, Anuratha CS, Sharma JK (1991) Bacteria wilt of Casuarina equisetifolia in India. Eur J Forest Pathol 21(4):234-238

Alvarez AM, Kaneshiro WS, Vine BG (2005) Diversity of Clavibacter michiganensis subsp. michiganensis populations in tomato seed: what is the significance? Acta Hortic 695:205-213
Athens SJ, Ward JV (2004) Holocene vegetation, savanna origins and human settlement of Guam. In a Pacific odyssey: archaeology and anthropology in the Western Pacific. Papers in honour of Jim Specht. Rec Aust Mus 29:15-30

Ayin CM, Schlub RL, Alvarez AM (2013) Identification of bacteria associated with decline of ironwood trees (Casuarina equisetifolia) in Guam. Phytopathology 103:S2.10

Ayin CM, Schlub RL, Yashuhara-Bell J, Alvarez AM (2015) Identification and characterization of bacteria associated with decline of ironwood (Casuarina equisetifolia) in Guam. Australas Plant Pathol 44:225-234. https://doi.org/10.1007/s13313-0140341-4

Bakshi BK (1951) Mortality of Casuarina equisetifolia Forst. Indian Forester 77:269-276

Brenner DJ, Krieg NR, Garrity GM, Staley JT (2005) Bergey's manual of systematic bacteriology: volume two. Springer, New York

Cibrián TD, Alvarado DR, García SED (Eds.) (2007) Enfermedades forestales en México/Forest diseases in Mexico. Universidad Autónoma Chapíngo; CONAFOR-SEMARNAT, México; Forest Service USDA, EUA; NRCAN Forest Service, Canada y Comisión Forestal de América del Norte; COFOAM, FAO. Chapingo, México. 221-228

Chen M, Lin L, Zhang Y, Sun L, An Q (2013) Genome sequence of Klebsiella oxytoca SA2, an endophytic nitrogen-fixing bacterium isolated from the pioneer grass Psammochloa villosa. Genome Announcements 1:e00601-e00613

Donnegan JA, Butler SL, Grabowiecki W, Hiserote BA, Limtiaco D (2004) Guam's Forest Resources, 2002. USDA, Forest Service, Pacific Northwest Research Station, Resource Bulletin, PNW-RB243

Engelbrecht MC (1994) Modification of a semi-selective medium for the isolation and quantification of Pseudomonas solanacearum. ACIAR Bacterial Wilt Newsletter Vol 10:3-5

Fegan M, Prior P (2005) How complex is the "Ralstonia solanacearum species complex"? Pages 449-461 in: Bacterial Wilt Disease and the Ralstonia solanacearum Species Complex. C. Allen, P. Prior, and A. C. Hayward, eds. American Phytopathological Society, St. Paul, $\mathrm{MN}$

Foroutan A, Jafary N (2007) Diversity of heart and root rot fungi on park and roadside trees in Maharashtra, India. J Appl Sci Environ Manage December 11(4):55-58

Fosberg FR, Sachet MH, Oliver R (1979) A geographical checklist of the Micronesian Dicotyledonae. Micronesica 15:41-295

Glen M, Bougher NL, Francis AA, Nigg SQ, Lee SS, Irianto R, Barry KM, Beadle CL, Mohammed CL (2009) Ganoderma and Amauroderma species associated with root-rot disease of Acacia mangium plantation trees in Indonesia and Malaysia. Australas Plant Pathol 38:345. https://doi.org/10.1071/AP09008

Gordon J, McLeod JW (1928) The practical application of the direct oxidase reaction in bacteriology. The J Pathol 31:185-190

Gregersen T (1978) Rapid method for distinction of gram-negative from gram-positive bacteria. World J Microbiol Biotechnol 5:123-127

Hartley C, Davidson RW, Crandall BS (1961) Wetwood, bacteria, and increased $\mathrm{pH}$ in trees. United States Department of Agriculture Forest Service in cooperation with the University of Wisconsin, Madison, WI

Hayward AC (1991) Biology and epidemiology of bacterial wilt caused by Pseudomonas solanacearum. Annu Rev Phytopathol 29:65-87

Hugh R, Leifson E (1953) The taxonomic significance of fermentative versus oxidative metabolism of carbohydrates by various gramnegative rods. J Bacteriol 66:24-26

Jeremic D, Cooper P, Srinivasan U (2004) Comparative analysis of balsam fir wetwood, heartwood, and sapwood properties. Can J For Res 34:1241-1250

Kaneshiro WS (2003) Detection and characterization of virulent, hypovirulent, and nonvirulent Clavibacter michiganensis subsp. 
michiganensis. (Master's thesis) Retrieved from the Graduate Division of the University of Hawaii at Manoa

Kogan S, Doherty M, Gitschier J (1987) An improved method for prenatal diagnosis of genetic diseases by analysis of amplified DNA sequences. N Engl J Med 317:985-990

Kohler F, Pellegrin F, Jackson G, McKenzie E (1997) Diseases of cultivated crops in Pacific Island countries. pp. 28-29

Kumar S, Stecher G, Li M, Knyaz C, Tamura K (2018) MEGA X: molecular evolutionary genetics analysis across computing platforms. Mol Biol Evol 35:1547-1549

Liang Z, Chen B (1982) Preliminary study on the susceptibility of Casuarina equisetifolia to Pseudomonas solanacearum and its relation to the permeability of the cell membrane and peroxidase isoenzymes. Journal of South China Agriculture: 1982-02

MacConkey T (1990) A note on a new medium for the growth and differentiation of the Bacillus coli communis and the Bacillus typhi abdominalis. Lancet 156(4010):20

Magnani G, Didonet C, Cruz L, Picheth C, Pedrosa F, Souza E (2010) Diversity of endophytic bacteria in Brazilian sugarcane. Genet Mol Res 9:250-258

Mersha Z, Schlub RL, Moore A (2009) The state of ironwood (Casuarina equisetifolia subsp. equisetifolia) decline on the pacific island of Guam. Phytopathology 99:S85

Mersha Z, Schlub RL, Spaine PO, Smith JA, Nelson SC (2010a) Visual and quantitative characterization of ironwood tree (Casuarina equisetifolia) decline on Guam. Phytopathology 100:S82

Mersha Z, Schlub RL, Spaine P, Smith J, Nelson S, Moore A, McConnell J, Pinyopusarerk K, Nandwani D, Badilles A (2010b) In Fungal associations and factors in Casuarina equisetifolia decline, 9th International Mycological Congress, Edinburgh, UK:IMC9:P3.268

Mersha Z, Aime MC, Cannon PG, Nandwani D, Nelson S, Spaine PC, Schlub RL (2011) Decline of Casuarina equisetifolia (ironwood) trees on Guam: Ganoderma and Phellinus. Phytopathology 101: S216

Mohanan C, Sharma JK (1993) Diseases of Casuarina equisetifolia in India. Commonwealth Forest Review 72:21

Murdoch CW, Campana RJ (1983) Bacterial species associated with wetwood of elm. Phytopathology 73:1270-1273

Norman D, Alvarez AM (1989) A rapid method for presumptive identification of Xanthomonas campestris pv. diffenbachiae and other xanthomonads. Plant Dis 73:654-658

Orian G (1961) Diseases of filao (Casuarina equisetifolia) forest in Mauritius. Revue agricole et sucriere de I'lle Maurice 40:17-45

Park JS, Husseneder C, Schlub RL (2019) Morphological and molecular species identification of termites attacking Ironwood trees, Casuarina equisetifolia (Fagales: Casuarinaceae), in Guam. J Econ Entomol 112(4):1902-1911. https://doi.org/10.1093/jee/toz097

Potgieter L, Richardson D, Wilson J (2014) Casuarina: biogeography and ecology of an important tree genus in a changing world. Biol Invasions 16:609-633

Quecine MC, Araujo WL, Rossetto PB, Ferreira A, Tsui S, Lacava PT, Mondin M, Azevedo JL, Pizzirani-Kleine AA (2012) Sugarcane growth promotion by the endophytic bacterium Pantoea agglomerans 33.1. Appl Environ Microbiol 78:7511-7518

Safford EW (1905) Useful Plants of Guam. U.S. Government Printing Office. Facsimile printing 2009 - Jillette Leon-Guerrero/ Guamology Publishing, $416 \mathrm{pp}$

Saitou N, Nei M (1987) The neighbor-joining method: a new method for reconstructing phylogenetic trees. Mol Biol Evol 4:406-425

Sakamoto Y, Sano Y (2000) Inhibition of water conductivity caused by watermark disease in Salix sachalinensis. IAWA J 21:49-60

Schink B, Ward JC, Zeikus JG (1981) Microbiology of wetwood: importance of pectin degradation and clostridium species in living trees. Appl Environ Microbiol 42:526-532

Schlub KA (2010) Investigating the ironwood tree (Casuarina equisetifolia) decline on Guam using applied multinomial modeling
LSU Master's Theses 2676. https://digitalcommons.lsu.edu/ gradschool theses/2676. (etd. 10282012-173615)

Schlub RL, Mersha Z, Aime CM, Badilles A, Cannon PG, Marx BD, McConnell J, Moore A, Nandwani D, Nelson SC, et al. (2011a) Guam ironwood (Casuarina equisetifolia) tree decline conference and follow-up, 4th International Casuarina Workshop, March 21-25, 210 Haikou, China. (Eds Zhong C, Pinyopusarerk K, Kalinganire A, Franche C), pp 239-246

Schlub RL, Moore A, Marx BD, Schlub KA, Kennaway L, Quintanilla M, Putnam M, Mersha Z (2011b) Decline of Casuarina equisetifolia (ironwood) trees on Guam: symptomatology and explanatory variables. Phytopathology 101:S216

Schlub RL, Mendi RC, Aiseam CC, Davis JK, Aime MC (2012a) Survey of wood decay fungi or Casuarina equisetifolia (ironwood) on the islands of Guam and Saipan. Phytopathology 102:S4.106

Schlub RL, Schlub KA, Alvarez AM, Aime MC, Cannon PG, Persad A (2012b) Intergrated perspective on Guam ironwood tree decline, 60th Annual Western International Forest Disease Work Conference, Lake Tahoe, California, Brown, J., Comp., Ed. Lake Tahoe, California, pp 51-60

Schlub RL, Kubota R, Alvarez AM (2013) Casuarina equisetifolia decline in Guam linked to colonization of woody tissues by bacteria. Phytopathology 103:S2.128

Schneider KL, Marrero G, Alvarez AM, Presting GG (2011) Classification of plant associated Bacteria using RIF, a computationally derived DNA marker. PLoS One 6(4):e18496. https://doi.org/ 10.1371/journal.pone.0018496

Soil Survey Staff (2015) National Resources Conservation Service, United State Department of Agriculture. Web Soil Survey. https:// websoilsurvey.sc.egov.usda.gov/. Accessed 5 Feb 2019

Stone BC (1970) The Flora of Guam. Micronesica 6:1-659

Supriadi MK, Sitepu D (2001) Bacterial wilt disease of woody trees caused by Ralstonia solanacearum: a review. Jurnal Penelitian dan Pengembangan Pertanian 20:106

Tiedemann G, Bauch J, Bock E (1977) Occurrence and significance of bacteria in living trees of Populus nigra 1. Eur J For Pathol 7:364-374

Wang CF, Praphat K, Xie GL, Zhu B, Li B (2008) Bacterial wilt of mulberry (Morus alba) caused by Enterobacter cloacae in China. Plant Dis 92:483

Ward JC, Pong WY (1980) Wetwood in trees: a timber resource problem. Gen. Tech. Rep. PNW-GTR-112. Portland, OR: U.S. Department of Agriculture, Forest Service, Pacific Northwest Forest and Range Experiment Station. 59p

Weber OB, Videira SS, Luiz Simoes de Araujo J (2013) Identification of culturable endophytes in 'champaka'pineapple grown in an organic system. Afr J Agric Res 8:3422-3430

Wei C-Y, Lin L, Luo L-J, Xing Y-X, Hu C-J, Yang L-T, Li Y-R, An Q (2013) Endophytic nitrogen-fixing Klebsiella variicola strain dx120e promotes sugarcane growth. Biol Fertil Soils 50:657-666

Weisburg WG, Barns SM, Pelletier DA, Lane DJ (1991) 16s ribosomal DNA amplification for phylogenetic study. J Bacteriol 173:697-703

Witzel K, Gwinn-Giglio M, Nadendla S, Shefchek K, Ruppel S (2012) Genome sequence of enterobacter radicincitans dsm16656t, a plant growth-promoting endophyte. J Bacteriol 194:5469

Yasuhara-Bell J, Ayin CM, Hatada A, Yoo Y, Schlub RL, Alvarez AM (2015) Detection of Klebsiella variicola and K. oxytoca by loopmediated amplification. J Plant Pathol Microbiol 6:271

Zhu B, Chen M, Lin L, Yang L, Li Y, An Q (2012) Genome sequence of Enterobacter SP. strain SP1, an endophytic nitrogen-fixing bacterium isolated from sugarcane. J Bacteriol 194:6963-6964. https://doi. org/10.1128/JB.01933-12

Zhu B, Lou MM, Xie GL, Wang GF, Zhou Q et al (2011) Enterobacter mori sp. nov. associated with bacterial wilt on Morus alba L. J Syst Evol Microbiol 61:2769-2774 